\title{
OS MOVIMENTOS CAMPONESES E A SOBERANIA ALIMENTAR NACIONAL
}

\author{
João E. Fabrini* \\ Unioeste e UFGD **
}

Resumo: A soberania alimentar defendida pelos movimentos camponeses está relacionada à autossuficiência do País na produção de alimentos, ou seja, soberano será o país capaz de produzir alimentos suficientes para atender à demanda existente no seu território. A soberania alimentar possui conteúdo que vai além da problemática alimentar e nutricional, ou seja, possui um conteúdo que envolve a soberania nacional. A conquista da soberania alimentar está vinculada à realização da reforma agrária, que também se reveste de um sentido nacional, pois se constitui, no entendimento dos movimentos camponeses, como parte de um projeto de desenvolvimento nacional.

Palavras-chave: Movimentos camponeses. Soberania alimentar. Reforma Agrária.

\section{PEASANT MOVEMENTS AND NATIONAL FOOD SOVEREIGNTY}

Abstract: The food sovereignty defended by the peasant movements is related to the country's selfsufficiency in food production, that is, sovereign country will be able to produce enough food to meet the demand existing in its territory. Food sovereignty has content that goes beyond food and nutritional problems, that is, it has a content that involves national sovereignty. The conquest of food sovereignty is linked to the realization of agrarian reform, which also has a national meaning, since it constitutes, in the understanding of the peasant movements, as part of a national development project.

Keywords: Peasant movements. Food sovereignty. Land reform. 
A soberania alimentar defendida pelos movimentos camponeses está relacionada à autossuficiência do País na produção de alimentos, ou seja, soberano será o país capaz de produzir alimentos suficientes para atender à demanda existente no seu território. A soberania alimentar será possível se a produção de alimentos estiver sob responsabilidade dos camponeses, pois o agronegócio latifundiário não é capaz de garantir a soberania alimentar da nação. A partir de dados do IBGE (2006), é possível reconhecer que os camponeses são mais eficientes na produção de alimentos para a nação do que o agronegócio latifundiário. Aliás, a capacidade de produção de alimentos à nação confere status de existência e lugar social aos camponeses.

A soberania alimentar da nação está vinculada à realização da reforma agrária. Assim, a luta dos movimentos camponeses pela reforma agrária também se reveste de um sentido nacional, uma vez que a sua realização, além de atender à demanda dos camponeses por terra, serve a toda a sociedade nacional produzindo alimentos. A reforma agrária é parte de um projeto mais amplo do que o projeto dos camponeses, ou seja, é parte de um projeto de desenvolvimento nacional.

Acrescenta-se ao processo de construção da soberania alimentar nacional o papel protagonista do Estado-nacional, que se constitui numa instância política capaz de defender os interesses do País e garantir a soberania derivada da produção interna (nacional) de alimentos. Assim, observa-se que a soberania alimentar possui um conteúdo político, ideológico e territorial para além da problemática alimentar e nutricional, pois implica uma abordagem do problema alimentar que envolve a existência autônoma dos camponeses relacionada a um projeto de nação.

Nesse sentido, existe um conteúdo nacional implícito nas concepções e ações dos movimentos camponeses, como é o caso da soberania alimentar. O nacional, inclusive, contraditoriamente, é visualizado pelos movimentos camponeses como virtuoso e parte da emancipação dos sujeitos para construção da soberania popular.

\section{O Estado-nacional como paradigma de soberania}

Soberania é uma construção histórico-espacial e está relacionada ao poder, à autoridade e ao domínio sobre um determinado espaço exercido por uma pessoa, família, povo, classe, dentre outros, o que forma o território. Para os romanos, por exemplo, a soberania significava o poder supremo da majestade imperial. No período monárquico medieval o poder estava assentado no "sistema de suserania" de base carismática e intocável. Já o absolutismo monárquico inaugurou a soberania expressa no poder pessoal do monarca, sob a crença generalizada da origem divina desse poder (Loveira, 2004, p. 2).

A partir do final do século XVIII emergiu a centralidade do Estado moderno no exercício da soberania mediante consentimento nacional. A política dos modernos colocou o Estado no centro do poder sobre o espaço, formando o território nacional. 0 Estado-nacional se constituiu em pilar central para assegurar a independência, autonomia e liberdade dos povos, e consequentemente seu território, em contraponto à estrutura de poder feudal e absolutista.

A nação e seu Estado se revestiram de um sentido revolucionário à ordem feudal-clerical e absolutista. A expressão revolucionária do Estado-nacional teve seu auge na França, no final do século XVIII, com a Revolução Francesa.

\begin{abstract}
A Revolução Francesa destruiu os particularismos locais e derrotou os senhores feudais como também as revoltas contrarrevolucionárias, em especial a Revolta de Vendeia, em 1793, garantindo a centralização do poder e do Estado. Isso permitiu um enorme salto adiante, formando não somente um Estado nacional, como também um mercado nacional, destituindo os embaraços para o florescimento capitalista. Com o povo em armas, a jovem nação francesa combateu os ataques reacionários de seus vizinhos como também foi à ofensiva nas guerras da primeira e segunda coalizações, levando consigo as bandeiras revolucionárias, sendo recebidos nos territórios ocupados como libertadores dos povos da Europa. Com efeito, a questão nacional foi levada à pauta para esses povos, por conseguinte fomentando movimentos nacionais tanto de unificação das nações divididas em diferentes e pequenos Estados, quanto à libertação de nações oprimidas que se emanciparam em novos Estados nacionais (Ferro, 2014, p. 5).
\end{abstract}

Segundo Lacoste (1997), no contexto posterior a 1789, numa segunda fase revolucionária francesa, na batalha de Valmy, emergiu a ideia de "vida à nação". 0 autor considera a nação como um conjunto territorial de características espaciais que indica unidade e formação de um território nacional. Se por um lado representa a opressão, de outro, o autor visualiza na nação um conteúdo democrático, autônomo e "libertário", inclusive de combate às ideias recentes nacionalistas de extrema direita na França.

Em resumo: a ideia de nação na sua complexidade e na riqueza de sua evolução histórica não deve ser reduzida a slogans nacionalistas, nem aos esquemas contemporâneos. Se no passado essa ideia foi um argumento ou pretexto para a tirania, a opressão e a perseguição política, foi considerada por muitos homens também como independência e liberdade... 
$\mathrm{Na}$ verdade, desde suas origens, a idéia de nação está associada com a de democracia, incluindo as contradições atuais, que nos parecem inaceitáveis (Lacoste, 1997, p. 91. Tradução nossa)

\section{Embora a Revolução Francesa assumisse} posteriormente um conteúdo conservador, atendendo aos interesses da burguesia que demandava da formação de um sistema econômico-social nacional, essa revolução serviu de paradigma, referência e estímulo para diversos movimentos de libertação dos povos a partir da constituição de nação. São exemplares os movimentos de emancipação e libertação da opressão de povos latino-americanos exercida pelos países colonizadores no século XIX. A defesa da nação está presente, por exemplo, no movimento liderado por S. Bolívar e J. Marti para libertação das colônias americanas das nações metropolitanas. O movimento "26 de Julho", este no século $X X$, liderado por $F$. Castro, que dirigiu a Revolução Cubana triunfada em 1959, também está assentado no ideário de libertação nacional. Atualmente, o ideal bolivariano assume expressão importante na Alba (Aliança Bolivariana das Américas), liderada pela Venezuela e acompanhada por nações como Cuba, Bolívia, dentre outras.

No Brasil, destaca-se o movimento da Inconfidência Mineira no século XVIII, dentre outros. Conforme Vianna (2015, p. 3), utilizando como referência o pensamento de Euclides da Cunha em "Da Independência à República", as origens da nacionalidade e o papel do Estado nesse contexto ocorreram como um projeto de minorias eruditas para aglutinar um "povo disperso" e para implantar a teoria política liberal. Nesse contexto, observa-se ainda que as diversas nações (indígenas, por exemplo) existentes no Brasil foram aglutinadas pelos segmentos políticos dominantes em torno de um Estado-nacional' ${ }^{1}$.

A dimensão nacional assumiu conteúdo virtuoso porque foi entendida como portadora de resistência à dominação imperialista. Sustentando-se principalmente na ideia de "imperialismo como fase superior do capitalismo", cunhada por V. Lênin, muitos movimentos e setores organizados da sociedade (partidos, intelectuais, sindicatos, entidades, dentre outros) entenderam o imperialismo como dominação de uma nação sobre outra, o que fez emergir um nacionalismo de esquerda. Portanto, a dimensão nacional permitiu a emergência de um nacionalismo de esquerda em contraponto ao imperialismo.

A tese de "socialismo num só país" e a obra O marxismo e a questão nacional, de J. Stálin, consideraram que o nacionalismo pode contribuir para expandir a libertação internacional. A classe trabalhadora não estaria em

${ }^{1}$ Porto-Gonçalves (2006) defende a necessidade de pensar o Brasil como um Estado-territorial e não Estado-nacional, pois houve a agregação de territórios e não de nações em torno do Estado. Para o autor, o mais adequado, no caso brasileiro, é considerar um Estado-plurinacional e não um Estado-nacional, uma vez que houve em torno do Estado a "agregação" de diversas nações. contradição com a nação, pois é possível pensá-la sob a hegemonia dessa classe. A nação seria uma instituição opressora quando dominada por um "bloco de classes sob hegemonia da burguesia", conforme o entendimento de A. Gramsci. Assim, é possível verificar na constituição e no fortalecimento da nação um sentido emancipatório e libertador da opressão de nações dominantes do "sistema" internacional.

No caso brasileiro, autores como Florestan Fernandes, Caio Prado Jr. e Celso Furtado fundamentaram teoricamente sentido emancipatório na constituição da nação. Segundo Sampaio Jr. (1997), ao referir-se ao caminho "entre a nação e a barbárie", é possível extrair desses autores uma práxis emancipatória na dimensão nacional. A teorização dos três autores permite fundamentar um projeto de nação a partir da formação de um sistema econômico fora do desenvolvimento dependente e subordinado aos interesses do sistema capitalista mundial.

De acordo com Sampaio Jr. (1997), fundamentandose em F. Fernandes, C. Prado Jr. e C. Furtado, o Brasil emergiu como nação num contexto de dependência e subordinação à lógica de acumulação capitalista internacional, o que foi responsável pela geração de forte desigualdade social. A inserção subordinada e dependente do Brasil no sistema capitalista mundial, desde o período colonial, foi responsável por um bloqueio econômico, social, político e cultural, o que minou as bases para o desenvolvimento nacional.

Nesse sentido, há a necessidade de formação de um sistema econômico nacional autônomo e independente, pois a economia dos países subdesenvolvidos, como o Brasil, não se estruturou em bases próprias, ou seja, nacional. A economia nacional dos países subdesenvolvidos se estruturou em função dos objetivos econômicos dos países dominantes do sistema.

\begin{abstract}
A grande dificuldade consiste em gestar as estruturas de uma economia nacional, isto é, a formação de bases produtivas voltadas para dentro do País e as necessidades próprias da população que o habita; uma organização destinada a mobilizar e coordenar os recursos e o trabalho do País em função precípua da existência dos indivíduos e da comunidade nela enquadrados; e não servir antes a interesses estranhos (Prado Jr., 2000, p. 288).
\end{abstract}

A partir dessa concepção, no processo de formação de um sistema econômico nacional, deve-se considerar o papel do Estado-nacional, responsável por submeter a economia de mercado aos interesses coletivos. 0 Estadonacional seria uma força política capaz de "civilizar" o capitalismo, evitando a barbárie, pois somente o império do poder político pode submeter a racionalidade voraz do lucro individual do mercado capitalista. 
O estudo do desenvolvimento estrutura-se a partir da constatação de que o Estado-nacional constitui a única força capaz de "civilizar" o capitalismo, pois somente o império do poder político sobre a matriz espacial e temporal da sociedade pode submeter a racionalidade abstrata do lucro individual à racionalidade substantiva da coletividade. Por isso, o Estado-nacional individualiza-se como uma realidade própria dentro do sistema capitalista mundial (Sampaio Jr., 1997, p. 69).

Sampaio Jr. (1997, p. 180) ainda considera que o processo de fortalecimento da nação passa pela realização de uma revolução nacional (revolução democrática burguesa). O Estado-nacional deve ser responsável pela constituição de estruturas econômicas, sociais e culturais compatíveis com valores democráticos da nação. A revolução nacional seria portadora de duas tarefas fundamentais, ou seja, serviria para superar os obstáculos que impedem a penetração do capitalismo em bases nacionais e criaria condições para que as classes sociais se identificassem positivamente com o regime burguês, universalizando uma ordem competitiva em todo o território nacional. Nessa perspectiva, é possível apreender que o capital nacional é mais virtuoso do que o capital internacional, pois a burguesia nacional teria possibilidade de maiores lucros, dedicando-se mais à produção do que à especulação e ao rentismo.

Portanto, cabem à revolução burguesa duas tarefas fundamentais. De um lado, é necessário superar os obstáculos que impedem a penetração e o funcionamento do capitalismo em bases nacionais. De outro, o processo de constituição de estruturas estatais deve criar condições para que as classes sociais se identifiquem positivamente com o regime burguês, condição indispensável para a sua afirmação como sistema econômico e social dominante... O desafio consiste em universalizar a ordem social competitiva em todo o território nacional e consolidar a internalização de forças produtivas tipicamente capitalistas (Sampaio Jr., 1997, p. 180).

A realização da revolução burguesa brasileira deve fortalecer uma economia capitalista nacional para remover características atrasadas e formas econômicas arcaicas da sociedade brasileira, gestada no processo desigual e combinado do desenvolvimento. Segundo Fernandes (1981, p. 65), as forças arcaicas, combinadas ao cálculo capitalista dos processos modernos, não são um resíduo, mas parte do processo de acumulação que a revolução burguesa poderá remover ao instalar regras de mercado menos dependente da política do atraso.

Sob o capitalismo dependente, a persistência de formas econômicas arcaicas não é uma função secundária e suplementar. A exploração dessas formas e sua combinação com outras, mais ou menos modernas e até ultramodernas, fazem parte do "cálculo capitalista" do agente econômico privilegiado (Fernandes, 1981, p. 65).
Segundo Fernandes (1981), ainda, essa revolução burguesa somente será portadora de independência econômica e capaz de levar à construção de uma sociedade autônoma quando existir uma vontade nacional, ou seja, quando surgirem forças sociais organizadas comprometidas com a construção da nação brasileira. Mas a burguesia débil e atrasada do capitalismo dependente brasileiro não é capaz de operacionalizar essa revolução e fazer avançar o processo de desenvolvimento nacional.

A defesa do transplante da modernidade do centro para a periferia pela burguesia débil leva à perpetuação da dependência e do subdesenvolvimento. Somente um amplo movimento político combinado com setores marginalizados e classes trabalhadoras em torno de "querer coletivo" será capaz de fortalecer a nação e romper com a dependência e o subdesenvolvimento. 0 "querer coletivo", fundado num consenso democrático será capaz de fazer contraponto aos estamentos, às forças oligárquicas e à burguesia "atrasada" para avançar o desenvolvimento nacional ${ }^{2}$.

\begin{abstract}
A destruição de estamentos e de grupos sociais privilegiados constitui o primeiro requisito estrutural e dinâmico da constituição de uma sociedade nacional. Onde essa condição histórica não chega ou não pode concretizar-se historicamente, também não surge uma ação e, muito menos, uma nação que possa apoiarse num "querer coletivo" para determinar, por seus próprios meios, sua posição e grau de autonomia entre as demais sociedades nacionais do mesmo círculo civilizatório. Sob esse aspecto, a democratização da renda, do prestígio social e do poder aparece como uma necessidade nacional. É que ela e somente ela pode dar origem e lastro a um "querer coletivo" fundado em um consenso democrático, isto é, capaz de alimentar imagens do "destino nacional" que possam ser aceitas e defendidas por todos, por possuírem o mesmo significado e a mesma importância para todos. (Fernandes, 1981, p. 174-175).
\end{abstract}

Bresser-Pereira (2014), ao tratar da "construção política do Brasil", afirma que um amplo movimento político nacional é pré-condição para o desenvolvimento econômico do País. Esse movimento político será realizado a partir de coalizões, sobretudo de classes, ou seja, a revolução nacional no Brasil não será feita por uma classe, mas a partir de coalizões, pactos e alianças. Aliás, na concepção do autor, a própria origem do Estadonacional e Revolução Industrial ocorreu a partir de pactos e alianças de classes.

Portanto, contrariando a ideia basilar marxista de que "o conflito de classes move a história", Bresser-Pereira (2014) entende que o desenvolvimento e a revolução nacional serão resultado de uma aliança de classes. 0 autor acredita que a história da humanidade não é

${ }^{2}$ Martins (2010, p. 94) entende que no governo de Fernando Henrique Cardoso (FHC) iniciou-se um esvaziamento político das oligarquias com o avanço e o fortalecimento de uma base política democrática. Segundo o autor, tal avanço democrático não recebeu apoio do MST e do PT, que não foram capazes de ouvir o que dizia F. Fernandes. 
necessariamente história da luta e do conflito de classes, mas da coalizão e das alianças de classes.

Martins (2010), também, ao tratar da "política do Brasil mística e lúmpen”, dá subsídios para apreender que a reforma agrária no Brasil, por exemplo, virá a partir de um amplo movimento político construído a partir de coalizões, ou seja, a reforma agrária virá de coalizões e não de luta de classes. Conforme Martins (2010) ainda, o governo de FHC seria capaz de galvanizar tais alianças, mas o Movimento dos Trabalhadores Rurais Sem Terra (MST), refém de interesses partidários, não foi capaz de compreender esse processo. Além disso, o Movimento entende que a reforma agrária será feita exclusivamente pela luta dos trabalhadores, entendimento esse que se constitui num obstáculo para conquistas.

Verifica-se, dessa forma, que a nação moderna emergiu como paradigma de desenvolvimento a partir da formação de um mercado nacional capitalista. A formação da nação foi entendida como possibilidade de independência, libertação e autonomia dos povos, e, como destacado anteriormente, muitos autores depositaram confiança na centralidade política do Estado-nacional na construção da independência e da emancipação social. Mas observa-se que essa instituição (Estado-nacional) está sujeita às críticas diversas, sobretudo no contexto dos preceitos anarquistas e marxistas.

Marx e Engels (2001), desde um passado distante, fundamentam crítica à dimensão nacional ao afirmar no manifesto comunista que "os operários não têm pátria". Acrescentam ao questionamento da dimensão nacional a crítica feita pelos anarquistas em torno da luta para a construção de uma ordem libertária internacional como verificada nos versos de A Internacional, de Eugéne Pottier e Pierre Degeyter: "Bem unidos façamos; Nesta luta final; Uma terra sem amos; A Internacional”.

Lênin, em "Notas críticas à questão nacional", afirma que na democracia da classe trabalhadora há necessidade de combater a ideia de nação. Afırma que a nação é um fenômeno efêmero que deverá desaparecer com a abolição da propriedade privada.

A democracia dos trabalhadores coloca adiante a demanda: absoluta unidade e completa amalgamação dos trabalhadores de todas as nacionalidades em todas as organizações dos trabalhadores, sindicatos, cooperativas, consumidores, educadores e todas as outras, para contrabalançar os nacionalismos burgueses de todos os tipos. Apenas essa unidade pode salvaguardar a democracia, salvaguardar os interesses dos trabalhadores contra o capital - que já se tornou e é cada vez mais internacional - e salvaguardar os interesses do desenvolvimento da humanidade rumo a um novo modo de vida para qual os privilégios e a exploração serão alienígenas (Lênin, 1913, apud Ferro, 2014, p. 9).
A crítica à nação não está limitada ao campo teórico anarquista e marxista. Alphonse Lamartine, no século XIX, afirmava que "o egoísmo e o ódio têm uma só pátria. A fraternidade não”. Os ideais internacionalistas também podem ser verificados na defesa de uma república mundial pautada na hospitalidade, como na concepção de I. Kant (1795) em A paz perpétua, reportada por Boff (2014), ao tratar de recentes migrações internacionais. Nessa república mundial não haveria lugar para nacionalismo, xenofobia, preconceito e fundamentalismo.

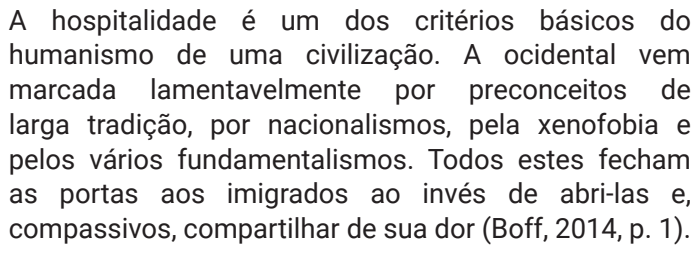

Sampaio Jr. (1997), embora visualize sentido virtuoso no Estado-nacional, como destacado anteriormente, o considera como uma instância historicamente determinada que deva ser ultrapassada por formas superiores de organização de alcance supranacional de poder ${ }^{3}$. O autor entende a "forma nacional" como um meio temporário de determinação dos povos no contexto do imperialismo.

\begin{abstract}
Pensada como um centro de poder que condensa a vontade política da coletividade, a forma nacional é aqui - única e exclusivamente - um meio das sociedades que vivem sobredeterminadas pelo campo de força do imperialismo controlarem o seu tempo histórico. Trata-se, portanto, de um instrumento historicamente determinado que deve ser ultrapassado por formas superiores de organização social e política, de alcance supranacional, assim que o contexto histórico mundial o permitir, isto é, assim que a ordem mundial deixar de estar sob o domínio de concorrência intercapitalista e das rivalidades imperialistas (Sampaio Jr., 1997, p. 154, grifo nosso).
\end{abstract}

Nesse contexto, Mészáros (2004), ao tratar do "poder da ideologia", levanta a necessidade de pensar numa alternativa global com a formação de um Estado mundial, semelhante à ideia de E. Kant de formação de uma república mundial. Segundo Martin (2011, p. 19), essa não é uma ideia viável, pois a paz mundial passa pela existência de concorrência e equilíbrio de forças entre potências, o que garante um mundo mais pacífico.

\footnotetext{
${ }^{3}$ Nessa perspectiva emergiram diversos projetos e ações de negação do Estadonacional como caminho de independência e autonomia dos povos. São ilustrativas as experiências recentes no Curdistão de negação do Estado-nacional como instância nuclear de poder a partir de dois movimentos: "Autonomia Democrática" e "Confederalismo Democrático". A materialização desse projeto negador do Estado-nação ocorreu nas cidades de Heseke e de Amed, com mais de 1,5 milhão de habitantes, dentre outras, organizadas em conselhos e assembleias em todos os níveis, conselhos de rua, conselhos de bairro e conselhos de distrito com a formação de um "sistema" rede. Assim, a "Autonomia Democrática" e o "Confederalismo Democrático" constituem um impulso ideológico e institucional para livrar-se do Estado e do capitalismo, substituindo estruturas representativas por práticas autônomas e participativas (Kolokotronis, 2015, p. 1).
} 
Mais viável é a ideia de equilíbrio de poder. É pelo receio que uma potência tem da outra que se pode estabelecer uma convivência pacífica no mundo. A dificuldade que domina o projeto unipolar é claro. Os Estados Unidos querem normas internacionais a partir de seus interesses, que o mundo respeite a globalização e o livre mercado, mas eles não se veem obrigados a acatar qualquer norma internacional... Só dá para pensar um mundo um pouco melhor com o equilíbrio de forças (Martin, 2011, p. 19).

Cataia (2011) elabora crítica ao projeto de Estado mundial, pois haveria dificuldade de estabelecimento do "governador" desse projeto. 0 autor considera ainda que o projeto de Estado mundial é uma proposta do Norte; organizado conforme a Europa se organiza. Além disso, considera que a formação de um Estado mundial implica uma homogeneização do mundo, semelhante a uma bola de bilhar, ou seja, um mundo não demarcado por fronteiras nacionais. Tomando como referência as ideias de J. Gottmann, Cataia (2011) visualiza sentido benfazejo na fronteira porque indica a existência de projetos diferentes. Os diferentes projetos se constituem numa beleza da humanidade.

Nessa perspectiva, a nação possui um sentido de emancipação, liberdade, independência e autonomia do território. A ausência de Estado-nacional pode ser compreendida como estágio de barbárie porque, quem iria governar o mundo se não o Estado? Acrescenta-se que a existência de nações, e inclusive fronteira entre elas, se constitui num aspecto virtuoso, pois baseia-se na existência da diversidade de projetos em contraponto ao pensamento único.

\begin{abstract}
A pergunta dele era: por que existem fronteiras? Existem porque os projetos são distintos. Para o Jean Gottmann, a beleza da humanidade, distinta dos animais, consegue construir projetos diferentes num mesmo ambiente físico, como o deserto do Saara, por exemplo. A ideia fundamental para a construção dessa unidade é pensá-la a partir do Sul (...). Então, é pouco provável que tenhamos um projeto que integre o mundo, pois quem o realizaria? (Cataia, 2011, p. 20).
\end{abstract}

Se no passado (século XVIII) o capitalismo demandou a ampliação espacial e a formação de um mercado nacional, posteriormente o mercado capitalista não se limitou ao território nacional, ampliando-se mundialmente. Marx e Engels (2001), no manifesto comunista de 1848, já apontavam para a "vocação" internacional do capital e sua expansão constante por toda a superfície do globo, dando um caráter cosmopolita à produção e ao consumo em todos os países.

A necessidade de um mercado em expansão constante para seus produtos persegue a burguesia por toda a superfície do globo. Precisa instalar-se em todos os lugares, acomodar-se em todos os lugares, estabelecer conexão em todos os lugares. A burguesia, através de sua exploração do mercado mundial, deu um caráter cosmopolita para produção e consumo em todos os países... As indústrias nacionais antigas foram destruídas ou seguem sendo destruídas dia após dia. Elas são desalojadas por novas indústrias, cuja introdução torna-se questão de vida e morte para todas as nações civilizadas; por indústrias que não mais trabalha com matéria-prima nacional, mas matériaprima extraída de zonas distantes; cujos produtos são consumidos não só no próprio país, mas em todos os cantos do globo. Em lugar das antigas necessidades, satisfeitas pela produção do país, encontram-se novas necessidades, exigindo para satisfazê-las produtos de terra e clima distantes. No lugar da antiga reclusão e autossuficiência local e nacional, temos conexões em todas as direções, uma interdependência universal das nações (Marx; Engels, 2001, p. 15).

A mundialização do capital no início do século XX levou para aquilo que Luxemburgo (1988) e Lênin (2010), dentre outros autores, denominaram imperialismo, ou seja, quando a fase concorrencial capitalista foi ultrapassada pela fase monopolista, sobretudo com a financeirização do capital. Nesse processo de expansão espacial os grupos econômicos desenvolveram "braços" financeiros que, em muitos casos, se tornaram maiores do que o capital industrial e apresentaram grande poder de mobilização internacional de capitais.

Kautsky (1986), ao estudar o imperialismo, entendeu que poderá haver a implantação de uma paz mundial com a superação da concorrência mundial entre as firmas e nações!

Font e Rufí (2006) afirmam que a expansão global das relações capitalistas de produção está solapando a soberania nacional, ou seja, a nação e seu Estado estão perdendo capacidade de intervenção econômica, política, social etc. A emergência de órgãos multilaterais e supranacionais de poder sobre a economia e territórios, como o FMI, OMC, OCDE, Banco Mundial, dentre outros, sobretudo depois do Encontro de Breton Woods em 1944, foi um marco no processo de solapamento da capacidade de decisão do Estado-nacional. Nesse contexto de mundialização do capital a soberania nacional foi sendo minada porque as corporações privadas transacionais passaram a atuar à margem do controle de autoridades nacionais.

Acrescenta-se também ao contexto de surgimento de entidades supranacionais a emergência de organizações não institucionalizadas que formam um poder paralelo ao Estado sobre os territórios como as organizações criminosas e militares (Al Qaeda, Estado Islâmico, dentre outras). Mas, nesse contexto de emergência de organizações não institucionalizadas, surgiram também movimentos sociais mundializados, como a Via Campesina, por exemplo, mas com propósitos bem diferentes das organizações citadas anteriormente. Avançando na superação da instância nacional de poder, muitos países intensificaram suas relações no sentido de formar blocos de nações. 0 caso mais expressivo foi a 
formação da União Europeia a partir de ações diversas surgidas a partir da década de 1950. A partir da referência do "bloco europeu", surgiram posteriormente outros blocos de nações como o Mercosul, Nafta, Pacto Andino, dentre outros.

Inclui-se a esse contexto o avanço do projeto neoliberal a partir da década de 1980, sobretudo nos países da América Latina, que intensificou a perda do poder e da importância do Estado-nacional. 0 avanço do projeto neoliberal permitiu referir-se a um Estadomínimo. A privatização de empresas estatais, de vias de transporte e portos, por exemplo, iniciado nesse contexto, é um indicativo de materialização do projeto neoliberal, o que fez a nação e seu Estado perderem importância para corporações e organismos econômicos internacionais.

Segundo Sampaio Jr. (1997), na década de 1990 um conjunto de condições derivadas da globalização neoliberal fez o Brasil entrar num ciclo de reversão colonial a partir de medidas que estimularam a exportação de produtos primários. Para o autor, a implantação de medidas neoliberais no Brasil implicou a desnacionalização da economia brasileira.

$\mathrm{Na}$ lógica da ordem internacional hoje emergente, o desenvolvimento nacional fica excluído do horizonte de possibilidades dos países periféricos... Expostas à fúria da globalização e ao arbítrio dos países ricos, as nações emergentes ficam sujeitas a processos de reversão neocolonial que desarticulam seus centros internos de decisão e quebram a espinha dorsal do sistema econômico nacional (Sampaio Jr., 1997, p. 20/21).

Mas observa-se que esse processo de solapamento do poder do Estado sobre os territórios nacionais é desigual e contraditório, pois, mesmo no contexto da globalização, não são raros os exemplos de centralização de decisões do Estado-nacional, inclusive como suporte para expansão das corporações transnacionais. 0 Estado-nacional é importante para a globalização do capital porque são essenciais para o controle de salários, orçamento, força pública, carga tributária etc.

Apesar das transformações nas relações de poder com a globalização neoliberal e a emergência de "atores" institucionais e não institucionais de poder, o Estadonacional ainda se constitui numa instância nuclear e central de poder. Nessa perspectiva de importância e centralidade do Estado que H. Lefebvre (1978) referiuse ao "modo de produção estatal" quando aprofundou questões relacionadas ao papel do Estado na produção do espaço.

Contraditoriamente, a defesa do Estado-nacional também acabou se revestindo de um conteúdo conservador, nacionalista e patriótico, sobretudo a partir do início do século XX. Rui Barbosa, por exemplo, expoente da política liberal no Brasil, também visualizou sentido virtuoso na dimensão nacional ao expressar um patriotismo nacional. Conforme o autor, a pátria pode ser definida como uma família ampliada que tem por elementos orgânicos a honra, a disciplina, a fidelidade, a benquerença e o sacrifício.

A pátria não é ninguém: são todos; e cada qual tem
no seio dela o mesmo direito à ideia, à palavra, à
associação. A pátria não é um sistema, nem uma seita,
nem um monopólio, nem uma forma de governo: é
o céu, o solo, o povo, a tradição, a consciência, o lar,
o berço dos filhos e o túmulo dos antepassados, a
comunhão da lei, da língua e da liberdade (Barbosa,
1903, apud Magalhães, 1997, p. 3).

A partir da defesa da nação surgiram diversos "movimentos" nacionalistas de extrema direita. Esse foi o caso do nacional-socialismo na Alemanha, fascismo na Itália, integralismo no Brasil, dentre outros. Em nome da nação, tanto nos países periféricos e colonizados quanto nos países centrais, foram cometidas barbáries contra a humanidade como o genocídio armênio atentado pelo Império Otomano (1915-1923), o holocausto nazista (1933-1945), a limpeza étnica na guerra de independência da Croácia (1991-1995), a Guerra da Bósnia (1992-1995), dentre outras. Atualmente, é exemplar o nacionalismo de extrema direita da Frente Nacional na França, liderada por J. M. Le Pen, que tem obtido conquistas políticas e eleitorais, sobretudo com as dificuldades econômicas recentes da União Europeia.

A partir dessa abordagem sobre soberania e Estadonacional, verifica-se que, se de um lado, ele (Estadonacional) é virtuoso e emancipador, de outro lado, é conservador, antidemocrático e parte da expansão, inclusive mundial, das relações capitalistas de produção. Considerando os diversos autores e concepções, é possível afirmar que a temática da soberania a partir do Estado-nacional possui um conteúdo positivo e negativo; questionador e conservador de estruturas de dominação/ opressão.

Ainda que o Estado-nacional possua conteúdo virtuoso, ele está sujeito ao contexto de classes sociais, sendo "apropriado" pela classe dominante do modo capitalista de produção, ou seja, a classe capitalista. Por isso, embora haja algum avanço para os camponeses com o fortalecimento no Estado-nacional, este, na sociedade de classes, possui limites para a soberania e a emancipação.

A abordagem sobre a problemática e o tema da soberania e o Estado-nacional não é necessariamente o objetivo do artigo, mas construir suporte à discussão do conteúdo nacional implícito nas concepções e ações dos movimentos camponeses, como é o caso da soberania alimentar e da reforma agrária. As contradições sobre soberania e Estado-nacional apontadas não são somente contradições de ordem epistemológico-intelectual. São 
contradições também dos movimentos camponeses que ora questiona, mas também acredita e legitima a dimensão nacional como potencial emancipador, como será destacado a seguir.

\section{Soberania alimentar e os movimentos camponeses}

Os movimentos camponeses, sobretudo aqueles mais organizados, desenvolvem um conjunto de lutas e ações relacionadas ao ideário de soberania nacional. 0 sentido nacional das ações dos movimentos pode ser verificado na luta pela reforma agrária; contra desnacionalização de terras, pela soberania alimentar, bem como nas palavras de ordem, hinos, documentos, eventos, dentre outros.

A relação dos camponeses com a nação vem desde passado distante, quando eles foram colocados a serviço dos interesses nacionais, como nos projetos de colonização, por exemplo. Nos projetos de colonização, além de produzirem alimentos para a nação, os camponeses eram também soldados que garantiam o domínio territorial nacional, como no caso da fronteira Sul do Brasil. Mas a preocupação dos movimentos camponeses com a nação é relativamente nova.

A preocupação dos movimentos camponeses com a soberania nacional e a pátria pode ser verificada nas suas palavras de ordem, hinos e eventos do MST, por exemplo. O hino do MST elucida essa preocupação, pois indica a necessidade de construção de uma pátria livre edificada pelo punho erguido do poder popular operário e camponês.

Vem, lutemos, punho erguido/Nossa força nos leva a edificar/Nossa Pátria livre e forte/Construída pelo poder popular/Nossa força resgatada pela chama/da esperança no triunfo que virá/forjaremos desta luta com certeza/pátria livre operária camponesa/nossa estrela enfim triunfará! (Bogo; Oliveira, 1996, p. 10).

Além do hino do MST, são ilustrativas também as palavras de ordem do Movimento. A palavra de ordem "pátria livre: venceremos", bem como "Reforma agrária: por justiça social e soberania popular", estão definidas no $\mathrm{V}$ Congresso do Movimento realizado em junho de 2007 e indicam a preocupação com a pátria e a soberania nacional. Os versos da canção "Ordem e Progresso", de Zé Pinto, também são ilustrativos: "este é o nosso país, essa é a nossa bandeira, é por amor a esta pátria-Brasil, que a gente segue em fileira".

O Movimento dos Sem-Terra entende que a ausência de um projeto estratégico de desenvolvimento nacional pode implicar uma ameaça à soberania do País. Embora diferentes na compreensão dos movimentos, a soberania nacional está em sintonia com a soberania popular, pois uma fortalece a outra. Nesse sentido, é preciso garantir soberania do povo sobre o território, riquezas naturais, biodiversidade, água e sementes, por exemplo.

\begin{abstract}
Precisamos de políticas e práticas dos governantes que garantam a plena soberania de nosso povo, sobre nosso território, nossas riquezas naturais, minerais, nossa biodiversidade, a água e as sementes. 0 Estado deve ter o controle com a participação da sociedade e dos trabalhadores, e das empresas estratégicas para o desenvolvimento nacional que já existem, e criar as que forem necessárias para gerir as riquezas. E instalar uma auditoria da dívida externa e examinar todos os contratos, para controlar a transferência de riquezas para o exterior, a título de juros e amortização de dívidas e de contratos não transparentes ou ilegais e imorais (MST, 2009, p. 1).
\end{abstract}

O VI Congresso Nacional do MST, realizado em 2014, enfatizou a necessidade de integração e ações conjuntas entre nações para alcançar soberania. Em contraponto à hegemonia internacional dos Estados Unidos (EUA), deve haver um esforço do Movimento para apoiar iniciativas de nações na construção de um mundo multipolarizado com o fortalecimento de nações como a China, Rússia, bem como a formação de blocos de países como a Alba (Aliança Bolivariana das Américas).

A Alba é considerada pelo MST como um projeto de integração popular de nações latino-americanas para cooperação política, econômica, cultural etc. Essa aliança visa também acumular forças para fazer frente às empresas transnacionais capitalistas das nações imperialistas e aos projetos hegemonizados pelos EUA. Para o MST, "a Alba busca acumular forças para derrotar as grandes empresas transnacionais e transitar para superar o capitalismo. É um projeto anti-imperialista" (Baggio, 2014, p. 1).

De acordo com Santos (2014), os países estão construindo resistências nacionais e formas de solidariedade regional sem "autorização" norteamericana. Segundo o autor, essa resistência nascida de nações latino-americanas pode se desdobrar numa nova "guerra fria" entre o capitalismo neoliberal e o capitalismo com alguma dimensão nacional e popular. Conforme Santos (2014), ainda, a agregação de nações é uma necessidade para que a democracia não seja capturada pelo capital, pois a nação em que o Estado tem maior intervenção na economia possui mais capacidade de controlar e regular o capitalismo. Nos EUA, por exemplo, a democracia se encontra refém e capturada pelo capital.

Entretanto, não são poucas as críticas a esses projetos de aliança entre nações, pois reproduzem contradições existentes entre países do "centro" do capitalismo na relação como sua "periferia". Este é o caso, por exemplo, da reprodução do modelo do agronegócio brasileiro gestado no Prodecer (Programa de Cooperação Nipo- 
brasileira para o Desenvolvimento do Cerrado), levado para a África no contexto do ProSavana (Programa de Cooperação Tripartite para o desenvolvimento Agrícola da Savana Tropical em Moçambique) numa associação entre capital brasileiro, japonês e africano, no caso, moçambicano. São exemplares também as críticas à iniciativa do banco do Brics (Brasil, Rússia, Índia, China e África do Sul), que reproduz em determinadas situações as relações estabelecidas entre nações latino-americanas e o Fundo Monetário Internacional, Banco Mundial etc.

Em resposta à articulação de nações do Sul e a expansão chinesa e russa, as superpotências comandadas pelos Estados Unidos ensaiam integração com países da América Latina como no Tratado Transpacífico (TPP) envolvendo Chile, Peru, Colômbia e México. Nesse contexto, contraditoriamente, estão também as alianças dos países latino-americanos com a China, que insistem em plataformas exportadoras primárias em vista da potência do mercado chinês.

A preocupação com a soberania nacional une também movimentos camponeses aos sindicatos de trabalhadores da indústria, como na formação do Comitê de Defesa do Petróleo Pela Soberania Nacional. O Comitê é formado por mais de 14 entidades, como o Sindicato Unificado dos Petroleiros/SP, Central Única dos Trabalhadores (CUT), Federação Única dos Petroleiros (FUP), Movimento dos Trabalhadores Rurais Sem Terra (MST), dentre outras, e visa garantir a posse das riquezas naturais, no caso o petróleo do pré-sal, sob controle do povo brasileiro. Segundo Antonio C. Spis, membro da executiva nacional da CUT, o Comitê organizou, a partir de 2008, a campanha "o pré-sal é do povo brasileiro" para assegurar o controle estatal e social do petróleo dentro de uma visão patriótica e nacionalista (CUT, 2008, p. 1).

A unidade dos movimentos camponeses e entidades diversas de trabalhadores na defesa de um projeto de nação podem ser verificadas também na formação recente (setembro de 2015) da Frente Brasil Popular. A frente reúne movimentos e entidades que estão preocupadas com questões nacionais como a soberania, defesa da economia nacional, patrimônio e riquezas nacionais, que se encontram ameaçadas de desnacionalização pelo grande capital. Trata-se da defesa do patrimônio nacional como se ele pertencesse a todo o povo brasileiro.

Outra preocupação dos movimentos camponeses relacionada à soberania nacional é a desnacionalização da terra, ou seja, a aquisição de terras por proprietários e empresas estrangeiras, facilitada por medidas recentes de liberalização da economia a partir da década de 1990. Os movimentos também visualizam consequências negativas para os camponeses com a desnacionalização das terras, pois a apropriação de terras nacionais por estrangeiros geralmente é acompanhada pela concentração de capitais. Assim, é possível entender que a terra apropriada por proprietários nacionais apresentaria menor ameaça à soberania da nação e seria mais benéfica para os camponeses.

Conforme Oyhantçabal (2014, p. 2), três fenômenos estão por trás da apropriação de terras por empresas estrangeiras em países latino-americanos e africanos: apropriação de uma renda internacional da terra; lógica cada vez mais especulativa da circulação internacional do capital; e investimentos em terras com finalidades de reserva de valor em vista da insegurança das moedas internacionais, ouro, títulos, ações de empresas etc.

A preocupação dos movimentos camponeses com a nação pode ver verificada também na defesa e na luta pela reforma agrária e a soberania alimentar, principalmente. Articuladas uma à outra, a soberania alimentar e a reforma agrária estão intrinsecamente vinculadas a um projeto nacional. Os movimentos entendem que os camponeses são imprescindíveis à nação em vista da sua capacidade de produzir alimentos para atendimento da demanda nacional, conferindo status de existência e lugar social para estes sujeitos (classe).

A luta dos movimentos camponeses pela reforma agrária no Brasil, se comparada à luta pela terra, é uma reivindicação relativamente recente, pois emergiu como maior força a partir da década de 1950 com a atuação das Ligas Camponesas. A luta dos camponeses pela reforma agrária é mais ampla do que luta pela terra, pois a sua realização está colocada pelos movimentos como uma necessidade do Brasil e não somente uma necessidade dos despossuídos da terra. O MST, por exemplo, defende a palavra de ordem "reforma agrária: uma luta de todos", ou seja, todos os brasileiros, e não somente os sem-terra, se beneficiarão com a realização da reforma agrária.

A reforma agrária é parte da construção de uma nação soberana porque o desenvolvimento nacional depende da distribuição de terras aos camponeses capazes de produzir alimentos para atender à demanda nacional e garantir a sua soberania. 0 projeto nacional implícito na reforma agrária está na capacidade e na eficiência dos camponeses de produzir alimentos e matérias-primas, necessárias para alavancar o desenvolvimento da nação. A realização da reforma agrária se justifica como parte de um projeto de desenvolvimento nacional e não somente como parte de um projeto camponês ou para resolver conflitos agrários. Portanto, a nação precisa da reforma agrária.

A eficiência produtiva dos pequenos agricultores, necessária para o desenvolvimento do Brasil, pode ser verificada nos dados da área cultivada e financiamentos para investimento e custeio de lavouras. Os pequenos agricultores, dispondo de apenas $24,3 \%$ da área total de terras do País (IBGE, 2006) e de 28 bilhões de reais em recursos financeiros (Plano Safra da Agricultura Familiar 2015-2016), são responsáveis por 33\% do PIB 
agropecuário. Eles produzem $100 \%$ de verduras, $87 \%$ de mandioca, $70 \%$ do feijão, $59 \%$ de suínos, $58 \%$ do leite, $50 \%$ de aves, $46 \%$ do milho e $38 \%$ do café, para ficar em alguns exemplos. Acrescenta-se que as pequenas propriedades empregam $74,4 \%$ dos trabalhadores e ocupam 15 pessoas a cada 100 hectares. A agricultura empresarial agronegócio - tem à sua disposição 159 bilhões de reais (Plano Safra 2015-2016), mas emprega apenas $25,6 \%$ dos trabalhadores e ocupa somente 1,7 pessoas a cada 100 hectares.

Nesse contexto, o lugar social e o status de existência da agricultura camponesa estarão garantidos pela eficiência e a capacidade produtiva de alimentos e matérias-primas para atender à demanda nacional. O lugar social dos camponeses se firma, nessa perspectiva, a partir de uma pauta econômica e não somente pela pauta política (luta e resistência). Nesse sentido, a dimensão econômica e a capacidade produtiva da agricultura camponesa, enfim uma pauta "desenvolvimentista", se fortaleceram no discurso dos movimentos camponeses de luta pela reforma agrária.

Martins (2010) afirma que houve alteração de prioridades na ação do que considera "mediadores" da reforma agrária na "nova república", quando a figura do posseiro foi substituída pela figura do sem-terra, deslocando o eixo central da questão da terra. Segundo o autor, a luta dos posseiros estava respaldada por um forte conteúdo moral, pois o grileiro era sinônimo de delinquente, criminoso e violento. Já a luta dos sem-terra não se deu com base no mesmo argumento moral, mas no argumento econômico.

Assim, o sentido soberano implícito na reforma agrária está na sua capacidade de alavancar o desenvolvimento nacional, pois as pequenas propriedades são mais produtivas e benéficas à nação. Conforme Grain (2014), uma organização internacional que visa apoiar agricultores de pequena escala e movimentos sociais na luta por sistemas alimentares dominados por comunidades locais, a pequena agricultura produz muito mais do que se poderia esperar de quem possui pequenas glebas. De acordo com Grain (2014, p. 58), ainda, as grandes propriedades, embora consumam mais recursos, controlam as melhores terras, possuem água para irrigação, infraestrutura, crédito financeiro, assistência técnica, utilizam insumos modernos e têm menor eficiência técnica e produtividade total.

Essa capacidade produtiva da pequena agricultura não é verificada somente na pequena agricultura brasileira. 0 quadro a seguir demonstra a capacidade de produção de alimentos de pequenas propriedades e área de terra ocupada em diversos países (ver Tabela 1).

No caso brasileiro, apesar da eficiência econômica da pequena agricultura, a reforma agrária não avança. Durante o governo de Dilma Rousseff houve forte diminuição do número de famílias assentadas, se comparado com os governos FHC e Lula, que assentaram em média ao ano 76.761 famílias (governo Lula) e 67.588 famílias (governo FHC). O governo Dilma, no primeiro mandado, assentou 26.838 famílias em média ao ano. 0 ano de 2015 foi de "decreto zero" para desapropriações de terra. Em 2016, ano do "golpe mídio-parlamentar", que destituiu a presidente do cargo, foram arrecadados 19,5 mil hectares resultantes de decretos de desapropriação no final do governo Dilma Rousseff, capazes de assentar apenas 784 famílias, conforme o "Painel dos Assentamentos" do Incra. Em 2016 ainda, durante o governo Temer, foi decretada a desapropriação de um único e minúsculo imóvel com área de 58 hectares para quilombolas.

Apesar da capacidade de produção e eficiência produtiva da pequena agricultura, ainda existem muitos segmentos sociais, inclusive intelectuais, que visualizam no agronegócio a garantia de produção de alimentos para o País e, consequentemente, soberania alimentar. A suposta produção do agronegócio justificaria, na concepção desses autores, a não realização da reforma agrária com distribuição de terras aos camponeses. Esses segmentos entendem que o fato de o Brasil ter passado de importador de alimentos na década de 1960 para exportador nos anos 2010 atesta a capacidade do agronegócio de produzir alimentos, contribuindo para a pauta de exportação e o equilíbrio das contas externas e da balança comercial (Navarro et al. 2014, p. 419).

Mas, para os movimentos camponeses, o agronegócio não é capaz de garantir a produção de alimentos para a nação e soberania alimentar nacional, pois sua principal preocupação é o lucro, a produção de mercadorias. A maior parte do que o agronegócio produz é para exportação e não necessariamente para o mercado interno, o que deixa a nação vulnerável.

Além da reforma agrária, como destacada anteriormente, o sentido nacional da luta dos movimentos camponeses pode ser verificado na defesa da soberania alimentar. A defesa da soberania alimentar se constitui numa das principais evidências do suporte nacional da luta dos movimentos camponeses, objeto principal da abordagem desse artigo. A ideia de soberania alimentar defendida pelos movimentos se constitui num projeto que apresenta uma conotação nacional, porque a nação soberana será aquela capaz de produzir alimentos para atender às necessidades do seu povo, ou seja, para uma nação ser soberana é necessário autoabastecimento nacional de alimentos, dentre outros requisitos.

A Via Campesina, a partir de conferência realizada em Tlaxcala, no México, em abril de 1996, definiu soberania alimentar como o direito de cada nação manter e desenvolver sua própria capacidade de produzir alimentos em bases camponesas, respeitando a diversidade cultural e os métodos de produção. Além 
da Via Campesina, outros movimentos camponeses também compartilham dessa compreensão e defendem a soberania alimentar, como o MPA (Movimento dos Pequenos Agricultores), MCP (Movimento Camponês Popular), ANA (Associação Nacional de Agroecologia), MPP (Movimento de Pescadores e Pescadoras Artesanais do Brasil), MAB (Movimento dos Atingidos por Barragens), MST, quilombolas, dentre outros, bem como sindicatos, partidos políticos, estudiosos, fóruns de entidades etc. Acrescenta-se à preocupação com a soberania alimentar nacional movimentos "internacionalizados", como a CLOC (Coordenadoria Latino-americana das Organizações do Campo), a Marcha Mundial das Mulheres, entre outros.

\begin{tabular}{|c|c|}
\hline País & $\begin{array}{c}\text { Produçāo de alimentos em pequenas } \\
\text { propriedades e quantidade } \\
\text { de terra que ocupa }\end{array}$ \\
\hline Bielorússia & $\begin{array}{l}\text { Com } 17 \% \text { da terra, os pequenos } \\
\text { agricultores produzem: } 87,5 \% \text { das frutas e } \\
\text { bagas; } 82 \% \text { das batatas; } 80 \% \text { das } \\
\text { hortaliças e } 32 \% \text { dos ovos. }\end{array}$ \\
\hline Botsuana & $\begin{array}{l}\text { As pequenas propriedades sāo } 93 \% \text { de } \\
\text { todos os estabelecimentos agropecuários, } \\
\text { têm menos de } 8 \% \text { da terra agrícola e } \\
\text { produzem: } 100 \% \text { do amendoim; } 99 \% \text { do } \\
\text { milho; } 90 \% \text { do milho miúdo; } 73 \% \text { do feijāo e } \\
25 \% \text { do sorgo. }\end{array}$ \\
\hline Brasil & $\begin{array}{l}84 \% \text { dos estabelecimentos rurais sāo } \\
\text { pequenos e correspondem a } 24 \% \text { da área total } \\
\text { ocupada por estabelecimentos rurais e } \\
\text { produzem: } 87 \% \text { da mandioca; } 69 \% \text { do feijāo; } \\
67 \% \text { do leite de cabra; } 59 \% \text { dos suínos; } 58 \% \text { do } \\
\text { leite de vaca; } 50 \% \text { das aves; } 46 \% \text { do milho; } 38 \% \\
\text { do café; } 33,8 \% \text { do arroz e } 30 \% \text { dos bovinos. }\end{array}$ \\
\hline $\begin{array}{l}\text { América } \\
\text { Central }\end{array}$ & $\begin{array}{l}\text { Com } 17 \% \text { da terra agrícola, os pequenos } \\
\text { agricultores produzem } 50 \% \text { de toda a } \\
\text { produção agrícola. }\end{array}$ \\
\hline Chile & $\begin{array}{l}\text { Em 1997, os pequenos agricultores eram } \\
\text { donos de } 6 \% \text { da terra e produziam: } 51 \% \text { das } \\
\text { hortaliças; } 40 \% \text { dos cultivos extensivos; } 26 \% \\
\text { dos cultivos industriais (beterraba açucareira, } \\
\text { calêndula, colza); } 23 \% \text { das frutas e uvas; } 22 \% \\
\text { dos cereais e } 10 \% \text { das pastagens. }\end{array}$ \\
\hline Cuba & $\begin{array}{l}\text { Com } 27 \% \text { da terra, os pequenos } \\
\text { agricultores produzem: } 98 \% \text { das frutas; } \\
95 \% \text { do feijāo; } 80 \% \text { do milho; } 75 \% \text { dos } \\
\text { suínos; } 65 \% \text { das hortaliças; } 55 \% \text { do leite de } \\
\text { vaca; } 55 \% \text { dos bovinos e } 35 \% \text { do arroz. }\end{array}$ \\
\hline Ecuador & $\begin{array}{l}\text { Quase } 56 \% \text { dos agricultores sāo pequenos e } \\
\text { têm menos de } 3 \% \text { da terra, mas produzem: } \\
\text { mais da metade das hortaliças; } 46 \% \text { do milho; } \\
\text { mais de um terço dos cereais; mais de um } \\
\text { terço dos legumes; } 30 \% \text { das batatas e } 8 \% \text { do } \\
\text { arroz. }\end{array}$ \\
\hline
\end{tabular}

\begin{tabular}{|c|c|}
\hline El Salvador & $\begin{array}{l}\text { Com apenas } 29 \% \text { da terra, os pequenos } \\
\text { agricultores produzem: } 90 \% \text { do feijāo; } 84 \% \\
\text { do milho e } 63 \% \text { do arroz, os três alimentos } \\
\text { básicos. A agricultura de quintal, inclusive } \\
\text { com superfícies agrícolas menores, provê } \\
51 \% \text { dos suínos, } 20 \% \text { das aves de quintal e } \\
\text { a maior parte das frutas tradicionais. }\end{array}$ \\
\hline Hungria & $\begin{array}{l}\text { As pequenas propriedades controlam } 19 \% \\
\text { da terra e obtêm } 25 \% \text { da margem bruta } \\
\text { padrāo total do setor agrícola }\end{array}$ \\
\hline Cazaquistāo & $\begin{array}{l}\text { Um pouco mais de } 97 \% \text { das propriedades } \\
\text { sāo pequenas e operam } 46 \% \text { da terra, } \\
\text { produzindo: } 98 \% \text { das frutas e bagas, } 97 \% \\
\text { do leite, } 95 \% \text { das batatas, } 94 \% \text { dos melōes, } \\
94 \% \text { das hortaliças, } 90 \% \text { da carne, } 78 \% \text { da } \\
\text { beterraba açucareira, } 73 \% \text { da calêndula, } \\
51 \% \text { dos cereais e } 42 \% \text { dos ovos. }\end{array}$ \\
\hline Quênia & $\begin{array}{l}\text { Em } 2004 \text {, com apenas } 37 \% \text { da terra, as } \\
\text { pequenas propriedades produziram } 73 \% \\
\text { da produção agrícola. }\end{array}$ \\
\hline Romênia & $\begin{array}{l}\text { As propriedades familiares sāo } 99 \% \text { de } \\
\text { todas as propriedades e têm } 53 \% \text { da terra, } \\
\text { com uma média de } 1,95 \\
\text { hectare/propriedade. Elas têm: } 99 \% \text { das } \\
\text { ovelhas; } 99 \% \text { das abelhas; } 90 \% \text { do gado; } \\
70 \% \text { dos suínos e } 61 \% \text { das aves de quintal. }\end{array}$ \\
\hline Rússia & $\begin{array}{l}\text { As pequenas propriedades têm } 8,8 \% \text { da } \\
\text { terra, mas participam com } 56 \% \text { da } \\
\text { produçāo agrícola, incluindo: } 90 \% \text { das } \\
\text { batatas; } 83 \% \text { das hortaliças; } 55 \% \text { do leite; } \\
39 \% \text { da carne e } 22 \% \text { dos cereais. }\end{array}$ \\
\hline Tajiquistāo & $\begin{array}{l}\text { As pequenas propriedades têm } 45 \% \text { da } \\
\text { terra e participam com } 58 \% \text { de toda a } \\
\text { produção agrícola. }\end{array}$ \\
\hline Ucrânia & $\begin{array}{l}\text { Os pequenos agricultores trabalham } 16 \% \\
\text { da terra agrícola, mas produzem } 55 \% \text { da } \\
\text { produçāo agrícola, incluindo: } 97 \% \text { das } \\
\text { batatas; } 97 \% \text { do mel; } 88 \% \text { das hortaliças; } \\
83 \% \text { das frutas e bagas e } 80 \% \text { do leite. }\end{array}$ \\
\hline
\end{tabular}

TABELA 1: Produção de alimentos em pequenas propriedades e quantidade de terra que ocupa

Fonte: Grain, 2014.

Embora os movimentos camponeses depositem sentido nacional na soberania alimentar, ela não está limitada à capacidade de produção de alimentos pelos camponeses de um país, mas também ao poder aquisitivo do seu povo. Assim, soberania alimentar implica a existência de condições para aquisição de alimentos produzidos na nação, pois, além da produção, essa soberania depende da capacidade de aquisição da população nacional, ou seja, depende da força do mercado de consumo nacional.

Além de condições necessárias para aquisição de alimentos produzidos nacionalmente, a soberania 
alimentar está relacionada às causas físicas, econômicas e sociais da nação. As distâncias de centro de consumo e comércio, capacidade de armazenagem, via de transporte, dentre outras condições infraestruturais, podem implicar dificuldade ou facilidade de acesso da população nacional aos alimentos produzidos pelos camponeses. Portanto, paradoxalmente, soberania alimentar não se constrói à parte do mercado de consumo nacional.

Desse modo, soberania alimentar não está relacionada exclusivamente à produção camponesa, embora ela se constitua seu pilar fundante. As decisões políticas e econômicas tomadas na esfera governamental relativas ao comércio internacional, como os acordos entre nações celebrados na OMC (Organização Mundial do Comércio), por exemplo, podem restringir ou ampliar a entrada de produtos agrícolas internacionais, desdobrando-se na produção camponesa de alimentos. As subvenções e os subsídios nacionais à produção de alimentar, bem como medidas protecionistas e estabelecimento de barreiras alfandegárias, estão diretamente relacionados à soberania alimentar, pois a produção camponesa não é algo à parte do contexto macroeconômico capitalista nacional e internacional. Enfim, soberania nacional alimentar depende também de decisões políticas e econômicas estruturais e não somente dos camponeses.

Mas esse conjunto de elementos, além de terra aos camponeses e reforma agrária, necessário para a soberania alimentar da nação, nem sempre são reconhecidos pelos movimentos camponeses. Os movimentos camponeses, embora tenham enfatizado a dimensão nacional, não fazem vinculação de soberania alimentar à estrutura econômica da nação, como se fosse possível alcançar essa soberania apenas a partir da produção camponesa. Os movimentos, ao mesmo tempo em que consideram a agricultura camponesa no contexto estrutural e macroeconômico, enfatizam que a soberania alimentar será alcançada a partir da produção camponesa.

Existem algumas compreensões de movimentos camponeses, intelectuais e organismos multilaterais que colocam a produção de alimentos em contraposição à produção de agrocombustível, sobretudo quando esta é realizada pelo agronegócio. Na compreensão desses segmentos, a soberania alimentar está em contradição com soberania energética, pois a produção de agrocombustível como o álcool, por exemplo, pode reduzir a área de cultivos e produção de gêneros alimentares, e consequentemente na elevação dos preços no mercado interno (nacional). Assim, nessa compreensão, a produção de agrocombustíveis é uma ameaça à produção de alimentos.

Entretanto, alguns movimentos entendem que não há contradição entre a produção de alimentos e de agrocombustíveis. O MPA (Movimento dos Pequenos
Agricultores) e a Via Campesina, dentre outros, possuem uma proposta de construção da soberania energética em harmonia com a soberania alimentar. Esta proposta está assentada numa base produtiva camponesa, em que se concilia produção alimentar e produção energética expressa no conceito de Alimergia, sustentado naquilo que o MPA denomina de Sistema Camponês de Produção (SCP).

A Cooperativa Mista de Produção, Industrialização e Comercialização de Biocombustíveis do Brasil Ltda (Cooperbio), vinculada ao MPA, por exemplo, localizada no Rio Grande do Sul, passou a operacionalizar a implantação da proposta de Alimergia.

\begin{abstract}
Os biocombustíveis podem ser produzidos em modelos alternativos que integrem a produção de alimentos, energias renováveis e serviços ambientais em sistemas descentralizados organizados pela agricultura camponesa. Este modo de produção está focado na autonomia energética em níveis de unidade de produção, comunitária, territorial e interterritorial de forma a articular-se com os sistemas de produção de alimentos, serviços ambientais e com a ocupação popular do território, garantindo suporte econômicoecológico sustentável à produção e reprodução de sistemas camponeses e sua relação com as cidades, integrando estes dois sistemas em um contínuo de trocas materiais, energéticas e econômicas (Cavalett; Leal; Rydberg, 2010, p. 2).
\end{abstract}

O MPA elaborou, inclusive, um plano para orientar suas ações, ou seja, um Plano Camponês que contempla a soberania alimentar, energética, genética e hídrica. Segundo o MPA, a soberania alimentar implica a produção e a comercialização de base local, agricultura diversificada para não depender de mercados oligopolizados e o não uso de agrotóxicos para garantir equilíbrio ambiental. A soberania energética diz respeito à produção, controle e autoconsumo de energia, o que implica uma mudança da matriz energética, pois o País possui diversas fontes de energia que ainda são pouco exploradas. A soberania genética está relacionada ao controle das sementes e mudas pelos camponeses, pois estes não podem ficar reféns das sementes transgênicas, controladas pelos grandes laboratórios. Por fim, a soberania hídrica trata de desenvolver pequenos sistemas de irrigação, coleta e armazenamento de água que não geram dependência externa.

Assim, movimentos, entidades sindicais, cooperativas, dente outros segmentos, reconhecendo possibilidade de obtenção de benefícios para os pequenos agricultores, defendem participação dos camponeses no projeto de produção de agrocombustível, disputando inclusive o projeto e o território com o agronegócio, como na produção de biodiesel, por exemplo. Esses segmentos entendem que os camponeses poderão protagonizar no desenvolvimento da nação, contrariando a concepção de que eles possuem somente interesses localizados, 
imediatos e corporativos porque não têm um projeto de totalidade e universalidade de existência.

Nesse contexto, muitos governos estão incorporando aos seus projetos a preocupação com a alimentação da nação. Mas, na esfera governamental e das políticas públicas, essa preocupação com a produção de alimentos se expressa na concepção de segurança alimentar e nutricional que não possui o conteúdo político e ideológico da soberania alimentar. A preocupação dos governos com a segurança alimentar e nutricional é estimulada principalmente pela FAO (Organização para Alimentação e Agricultura), uma organização da ONU (Organização das Nações Unidas) dedicada à alimentação e à agricultura.

A FAO, que elaborou plano para combater a fome no mundo na Cúpula Mundial da Alimentação em 1996, considera que segurança alimentar e nutricional implica a garantia de alimentos básicos de modo permanente para a existência digna e integral da pessoa humana.

Segurança alimentar e nutricional significa garantir, a todos, condições de acesso a alimentos básicos de qualidade, em quantidade suficiente, de modo permanente e sem comprometer o acesso a outras necessidades essenciais, com base em práticas alimentares saudáveis, contribuindo, assim, para uma existência digna, em um contexto de desenvolvimento integral da pessoa humana (FAO, op. cit., Menezes, 2015).

A partir dessa deliberação, muitos países tomaram medidas governamentais para garantir a segurança alimentar e nutricional do povo. No caso brasileiro, o governo federal tomou uma série de medidas, como a aprovação em 2006 da lei n. 11.346/2006 (Losan - Lei Orgânica de Segurança Alimentar e Nutricional) e instituiu o Sisan (Sistema Nacional de Segurança Alimentar e Nutricional), responsável em planejar, implementar, coordenar, supervisionar e acompanhar programas, projetos e ações de SAN (Segurança Alimentar e Nutricional), de acordo com a Política Nacional de Segurança Alimentar e Nutricional.

Segundo a Losan, seguindo plano de combate à fome traçado na Cúpula Mundial da Alimentação organizada pela $\mathrm{FAO}$, a segurança alimentar e nutricional pode ser definida como a garantia do acesso regular e permanente de alimentos de qualidade e quantidade suficiente considerando práticas alimentares capazes de promover a saúde, respeitar a diversidade cultural, ambiental, econômica e ser socialmente sustentáveis (CONSEA, 2006, p. 4).

Inserida também nesse contexto está a criação e a retomada do Conselho Nacional de Segurança Alimentar e Nutricional (Consea) e a criação de Conselhos Estaduais e Municipais, bem como o Plano Brasil sem Miséria, visando à erradicação da fome e da miséria no Brasil.
O Brasil tem realizado grandes avanços no campo da segurança alimentar e nutricional desde 2003, quando lançada a Estratégia Fome Zero. Ao eleger como prioridade o combate à fome e à pobreza, o Governo Federal fortaleceu e criou políticas públicas que se mostraram efetivas para a melhoria das condições sociais e de alimentação dos grupos sociais mais vulneráveis. Igualmente importante foi o processo de institucionalização desta política, que se inicia com a promulgação da Lei n. 11.346/2006, a Lei Orgânica de Segurança Alimentar e Nutricional (Losan), que criou o Sistema Nacional de Segurança Alimentar e Nutricional (Sisan) e estabeleceu as bases para a construção da Política e do Plano Nacional de Segurança Alimentar e Nutricional. Este processo realiza-se por meio da adoção de mecanismos de participação social, com a retomada do Conselho Nacional de Segurança Alimentar e Nutricional (Consea) e a criação dos Conselhos Estaduais e Municipais congêneres, e possui como base e vetor a realização do Direito Humano à Alimentação Adequada (DHAA), que, em 2010, foi literalmente expresso em nossa Constituição Federal.(Brasil, 2011, p. 15).

Apesar de a segurança alimentar passar pelas decisões governamentais de cada nação, a sua concepção não possui uma conotação nacional bem definida e moldada como aquela verificada na ideia de soberania alimentar, pois para a segurança alimentar e nutricional não importa se alimentação é produzida no País ou fora dele. A segurança alimentar e nutricional está relacionada às políticas governamentais para garantir o abastecimento independente da origem nacional dos alimentos, ou seja, se o alimento é produzido nacionalmente ou importado.

Entretanto, após a Cúpula Mundial da Alimentação da FAO, o conceito de segurança alimentar e nutricional foi assumindo características relacionadas à segurança nacional, pois a fome e a miséria poderão ameaçar a estabilidade e gerar inquietações num determinado país, tornando-o inseguro, motivando inclusive migrações para outros países. Assim, segurança alimentar também possui preocupação nacional, mas numa perspectiva diferente de soberania alimentar; aliás, esta surgiu, inclusive, como contraponto à segurança alimentar.

Apesar dessa preocupação com a estabilidade dos países, o conceito de segurança alimentar não possui um conteúdo nacional explícito se comparado com a soberania alimentar. Acrescenta-se que, enquanto a segurança alimentar possui um sentido menos ideologizado, defendido por governos, setores oficiais, organismos multilaterais diversos, inclusive perpassando interesses de empresas e corporações capitalistas, a soberania alimentar é defendida por movimentos camponeses e possui conteúdo nacional e classista bem definido. Está implícito no conceito de soberania alimentar um conteúdo político e ideológico vinculado aos movimentos e lutas dos camponeses, fazendo com que soberania alimentar se constitua numa concepção maior do que produzir alimentos e combater a fome. 
As agências internacionais de desenvolvimento frequentemente alertam os governos para a necessidade de aumento da produção de alimentos nas próximas décadas, recomendando, para alcançar esse objetivo, a liberalização do comércio e investimentos em tecnologias para alcançar a soberania segurança e nutricional. Mas, segundo diferentes organizações populares e movimentos camponeses, como a Via Campesina e Grain, por exemplo, esse objetivo somente será alcançado se se entregar os meios de produção aos camponeses e povos indígenas para que seja garantida a produção de alimentos para a população do País e do mundo.

Assim, se a soberania alimentar está diretamente vinculada à ideia de nação, como destacado anteriormente, ela não se limita a essa dimensão, o que exige um alargamento da compreensão desse conceito, ou seja, há necessidade de reconhecer o sentido de classe, no caso, "classe" camponesa. A soberania alimentar envolve também temas relacionados ao direito de atendimento das necessidades humanas básicas de alimentação e nutrição; produção e comercialização local dos alimentos, afastando-se da produção de alimentos controlados por corporações transnacionais; contraponto às monoculturas ao afirmar-se na diversidade da produção camponesa; preocupação ambiental e uso de venenos prejudiciais à saúde das pessoas; dentre outras. Portanto, a soberania alimentar possui uma perspectiva mais ampla, para além do sentido nacional, que envolve resistências à imposição aos padrões, hábitos, costumes e modelos alimentares controlados por corporações empresariais capitalistas nacionais e transacionais.

De acordo com o MPA, a soberania envolve a preocupação com a preservação dos recursos naturais sem contaminação do solo, água, ar etc. Nesse contexto está contemplada a utilização de insumos orgânicos como adubação verde, sementes crioulas, defensivos naturais, utilização de mecanização leve, preservação de matas ciliares e fontes de água e uso de tecnologias de produção, colheita, secagem e armazenagem simples. Os processos de transformação para agregação de valor aos produtos devem ser feitos em base local e cooperativada, considerando os métodos de higiene e saúde (embora a legislação sanitária dificulte estas atividades). Ainda segundo o MPA, soberania alimentar envolve sistemas locais de produção e circulação de produtos alimentares sem intermediação de esquemas empresariais de grandes grupos corporativos. Por fim, a soberania alimentar implica uma organização produtiva familiar feita sem a exploração, sujeição e subordinação do trabalho ou renda do outro, ou seja, a soberania está assentada em bases camponesas de produção.

Essa base organizativa da produção de alimentos comunica-se com o "empoderamento" dos sujeitos por meio de associações diversas, fortalecendo-as politicamente para participar de processos decisórios em diversas esferas. Acrescenta-se a esse contexto a capacidade reivindicativa e de alocação de políticas públicas voltadas ao atendimento dos pequenos agricultores, visando forjar um território livre e autônomo. A produção sobre bases camponesas implica a construção da uma autonomia produtiva, o que se desdobra numa soberania sobre os territórios a partir da produção de alimentos.

Observa-se que uma das características fundantes do campesinato é a dedicação à produção de mercadorias e de autoconsumo. Embora soberania alimentar implique uma relação com o mercado local e nacional, a produção para o autoconsumo dos camponeses poderá garantir aquilo que Wolf (1970) denominou de "mínimo calórico" e Cândido (2003) denominou de "mínimo vital", ou seja, uma produção destinada ao autoconsumo capaz de garantir sobrevivência dos membros da família.

Enquanto a perspectiva de soberania alimentar remete à produção de alimentos numa perspectiva externa, para a nação a produção de autoconsumo remete à produção interna de alimentos. Essa capacidade de produção para a família, embora nenhum camponês sobreviva somente da produção de autoconsumo, garante autonomia, comando e independência produtiva, ou seja, comando do seu território ${ }^{4}$.

Assim, se, de um lado, soberania alimentar pressupõe existência autônoma dos camponeses, ou seja, a conquista de território livre e autônomo a partir da sua capacidade de produzir alimentos, de outro lado pressupõe que a autonomia camponesa será alcançada a partir do atendimento dos interesses da nação e do mercado nacional. Nesse caso, urge a necessidade de pensar numa produção camponesa de alimentos para atender às classes populares e aos próprios camponeses e não necessariamente aos interesses nacionais.

\section{Considerações finais}

A partir da abordagem feita neste artigo, é possível chegar a um conjunto de verificações sobre "os movimentos camponeses e a soberania alimentar nacional".

Verifica-se que existe um sentido nacional na luta dos movimentos camponeses. A dimensão nacional é visualizada pelos movimentos como portadora de virtude, pois se constitui num caminho para alcançar

\footnotetext{
${ }^{4}$ Mas observa-se que não é toda a produção camponesa de alimentos que é capaz de formar território autônomo e livre da imposição de esquemas dominantes, pois, em muitos casos, a organização produtiva está subordinada às cadeias produtivas controladas por empresas e cooperativas capitalistas. A esse processo de controle do território camponês por corporações capitalistas Oliveira (2003, p. 477) denominou de "monopólio do território", ou seja, quando indústrias capitalistas processadoras de alimentos, por exemplo, extraem a renda da terra sem a necessidade de expropriar os camponeses.
} 
autonomia, liberdade, independência, enfim, soberania. O sentido nacional da luta dos movimentos camponeses pode ser observado de diversas formas, dentre as quais se destaca a defesa da soberania alimentar.

A soberania alimentar possui um conteúdo nacional porque considera que a produção de alimentos pelos camponeses poderá levar à soberania da nação, ou seja, umanaçãosomenteserásoberana setiverautossuficiência na produção de alimentos. A autossuficiência alimentar nacional e, consequentemente, a soberania serão alcançadas a partir da produção camponesa, pois o agronegócio, guiado pelos lucros e rendas, não será capaz de atender às demandas e garantir a soberania da nação. Nesse contexto emerge a necessidade da realização da reforma agrária, pois a distribuição de terra e garantia de condições de produção para os camponeses é uma necessidade para a autossuficiência nacional de alimentos.

Entretanto, se, de um lado, verifica-se que a produção de alimentos pelos camponeses pode garantir a soberania alimentar nacional, de outro lado, a produção de alimentos poderá se constituir caminho para a conquista de território livre, ou seja, para autonomia, emancipação e garantia do lugar social dos camponeses. Oxalá que o lugar social dos camponeses seja conquistado pela capacidade de produzir bens (alimentos) para atender à demanda da sociedade e não necessariamente aos interesses da soberania nacional. Enfim, que a produção camponesa de alimentos possa servir à soberania deles mesmos e não necessariamente à soberania de outros.

\section{Referências}

BAGGIO, R. (2014). Integração latino-americana é a forma para alcançar soberania. Disponível em: <http//www.mst.org. br/node/15725>. Acessado em: 13 de fevereiro de 2014.

BOGO, A.; OLIVEIRA, W. C. (1996). Hino do Movimento Sem-Terra. In: MST. As músicas do MST. Porto Alegre: Unidade Editorial.

BRASIL/MDS. (2011). Plano Nacional de Segurança Alimentar e Nutricional: 2012/2015. Brasília: Caisan.

BOFF, L. (2014). A hospitalidade para com os haitianos: quão humana é a nossa sociedade? Disponível em: <http//www. ihu.unisinos.br/noticias/530965>. Acessado em: 17 de setembro de 2015.

BRESSER-PEREIRA, L. C. (2014). A construção política do Brasil. São Paulo: Editora 34.

CÂNDIDO, A. (2003). Os parceiros do rio Bonito. São Paulo: Duas Cidades.

CATAIA, M. A. (2011). Fronteiras: territórios em conflitos. Geografia em Questão. V. 4, n. 2, p. 11-25.

CAVALETT, O.; LEAL, M.; RYDBERG, T. (2010). Avaliação Emergética de Sistema Camponês de Produção de Álcool, Alimentos e Serviços Ambientais. In: LEAL, M. Agricultura e mudanças climáticas. A contribuição dos sistemas camponeses de produção para uma agricultura sustentável. Palmeira das Missões: MPA.

CONSEA. (2006). Lei de segurança alimentar e nutricional - conceitos. Brasília: Consea.

CUT (2015). Comitê de Defesa do Petróleo pela Soberania Nacional em campanha por controle estatal e social: CUT, FUP, MST e mais 14 entidades unidas em SP. Disponível em: <http//www.cut.org.br. 2008>. Acessado em: 21 de setembro de 2015.

FERNANDES, F. (1981). Sociedade de classes e subdesenvolvimento. Rio de Janeiro: Zahar. 
FERREIRA, L. (2013). MPA realiza Jornada Nacional de Lutas por Soberania Alimentar em todo o País. Brasil de Fato. Disponível em: <http//www.brasildefato.com.br/node/26332>. Acessado em: 22 de setembro de 2015.

FERRO, A. M. F. (2014). Nação, nacionalismo e os trabalhadores frente à questão nacional. Disponível em: <http//www. marxismo.org.br/content>. Acessado em: 17 setembro 2015.

FONT, J. N.; RUFÍ, J. V. (2006). Geopolítica, identidade e globalização. São Paulo: Anablume.

FURTADO, C. (1959). Formação econômica do Brasil. Rio de Janeiro: Paz e Terra.

GRAIN (2014). Famintos de terra: os povos indígenas e camponeses alimentam o mundo com menos de um quarto da terra agrícola mundial. Disponível em: <http//www.humanitas.org.br>. Acessado em: 12 de agosto de 2015.

KAUTSKY, K. (1986). A questão agrária. São Paulo. Nova Cultural.

KOLOKOTRONIS, A. (2015). A solução sem Estado. Institucionalização do Socialismo Libertário no Curdistão. Comité de Solidaridad con Rojava e el Pueblo Kurdo. Tradução de André Langer. Disponível em: <http://www.humanitas.org.br>. Acessado em: 26 de março de 2015.

LACOSTE, Y. (1997). Vive La Nation. Paris: Librarie Arthème Fayard.

LEFEBVRE, H. (1978). De L'État - Les Contradictions de l'État Moderne. Paris: Union Générale d'Édition.

LÊNIN, V. I. (2010). El imperialismo: fase superior del capitalismo. La Habana: Editorial de Ciencias Sociales.

LOVEIRA, (2004). Teoria Geral do Estado: Soberania. Disponível em: <http://www.loveira.adv.br/material/tge7.htm>. Acessado em: 22 de setembro de 2015.

LUXEMBURGO, R. (1988). A acumulação do capital. São Paulo: Nova Cultural.

MAGALHÃES, R. M. M. A. (1997). Atualidade de Rui. Fundação Casa de Rui Barbosa. Disponível em: <http//www.casaruibarbosa.gov.br>. Acessado em: 22 setembro de 2015.

MARTIN, A. R. (2011). (Des) controle dos territórios (e de suas fronteiras) num mundo globalizado. Geografia em Questão. V. 4, n. 2, p. 13-21.

MARTINS, J. S. (2010). A formação política do Brasil. São Paulo: Contraponto.

MARX, K.; ENGELS, F. (2001). O manifesto comunista. São Paulo: Paz e Terra.

MENEZES, F. (2015). O conceito de segurança alimentar. Actionaid. Disponível em: <http//www.actionaid.org.br/img/ publics/faces_cap3.pdf>. Acessado em: 15 de maio de 2015.

MÉSZÁROS, I. (2004). O poder da ideologia. São Paulo: Boitempo.

MPA. (2013). Soberania Alimentar. Disponível em: <http://www.mpabrasil.org.br/soberania>. Acessado em: 15 de outubro de 2014.

MST. (2009). Nossas bandeiras: soberania nacional e popular. Disponível em: <http//www.mst.org.br/node/7709>. Acessado em: 21 de setembro de 2015.

NAVARRO, Z. et. al. (2014). 0 mundo rural no Brasil do século 21. Brasília; Embrapa.

OLIVEIRA, A. U. (2003). Agricultura brasileira: transformações recentes. In: ROSS, J. Geografia do Brasil. São Paulo: Edusp. OYHANTÇABAL, G. (2014). A "revolução" da agropecuária e a transnacionalização da terra. Disponível em: <http//www. humanitas.org.br>. Tradução de André Langer. Acessado em: 23 de maio de 2015.

PORTO-GONÇALVES, C. W. (2006). A nova des-ordem mundial. São Paulo: Edunesp.

PRADO JR., C. (1996). Formação do Brasil contemporâneo. São Paulo: Brasiliense.

(2000). A revolução brasileira. São Paulo: Brasiliense.

SAMPAIO JR., P. A. (1997). Entre a nação e a barbárie: uma leitura das contribuições de Caio Prado Jr., Florestan Fernandes e Celso Furtado à crítica do capitalismo dependente. Doutorado em Economia - Universidade Estadual de Campinas. Instituto de Economia. Campinas.

SANTOS, B. S. (2014). Brasil: a grande divisão. Disponível em: <http//www.humanitas.org.br>. Acessado em: 13 de novembro de 2014.

VELOSO, T. (2012). Subcomissão derruba restrições mais rígidas a venda de terras a estrangeiros. Valor Econômico. Disponível em: <http//www.ihu.unisinos.br>. Acessado em: 21 de setembro de 2015.

VIANA, L. W. (2015). As marcas de origem e a crise atual. Disponível em: <http//www.ihu.unisinos.br>. Acessado em: 22 de setembro de 2015.

WOLF, E. (1970). Sociedades camponesas. Rio de Janeiro: Zahar. 